\title{
INCOME TAXATION OF HUSBAND AND W/FE
}

TREATMENT in the Revenue Act of husband and wife as two entirely distinct individuals has made the marital relationship the factual background for much income tax litigation. Allowance to each spouse of full legal capacity ${ }^{1}$ cannot be reconciled with the fact of their economic unity. However emancipated the wife may have become, her income directly affects the ability of her husband to pay a tax. ${ }^{2}$ Yet the Act treats husband and wife as any other two individuals in permitting them to file separate returns and make valid transactions between themselves. By granting spouses the privilege of filing a joint return, Congress has in some degree recognized the economic autonomy of the family. ${ }^{3}$ But the extent to which real taxable unity has been established by the joint return privilege remains unsettled. Despite the unambiguous interpretation of the statute by the Bureau of Internal Revenue and the unanimous agreement of commentators that the statutory theory conceives of husband and wife as separate taxpayers, ${ }^{\mathbb{0}}$ spouses filing joint returns continue to insist that under this privilege their complete taxpaying unity is recognized. ${ }^{6}$

Concretely the question is whether the income of each spouse is to be determined separately and then combined with the other's total to find "aggregate income," or whether the gains and losses of both should be treated as the income of one taxpaying unit. ${ }^{7}$ It has been established that if the total of a wife's income results in a net loss, that figure may be deducted from a husband's income. 8 But this result could follow from either method of determining aggregate income, and a contrary rule would in many cases completely nullify the joint return privilege. The question becomes important,

1. Peck, Dontestic Relations (3d ed. 1930) 254 et seq.

2. Mrr. Justice Holmes refers to the wife's income as one "that in every probability will make his life easier and help to pay his bills." Hoeper v. Tax Comm., 234 U. S. 206, 220 (1931) (dissenting opinion).

3. 53 StAT. 27 (1939), 26 U. S. C. A. $\$ 51$ (b) (1940).

4. E.g., U. S. Treas. Reg. 86, Art. 117-5; U. S. Treas. Reg. 94, Art. 117-5. But a contrary view was expressed in a letter from the Commissioner quoted in 333 C. C. H. 1933 Fed. Tax Serv. If 6037.

5. Bruton, The Taxation of 'Family Income (1932) 41 YaLE L. J. 1172; Paul and Havens, Husband and $W^{\prime}$ ife under the lncome Tax (1936) 5 Beoorsyor L. Rev. 241; Reiling, Taxing the Inconc of the Hushand and Wife (1935) 13 TAx MAa. 198.

6. E.g., Janney v. Comm'r, 108 F. (2d) 564 (C. C. A. 3d, 1939).

7. U. S. Treas. Reg. 101, Art. 51-1(b), 117-5(a).

8. Parent v. Jones, 1 Prentice-Hall 1939 Fed. Tax Serv. I5.513 (W. D. Olia. 1939), no appeal, 1 Prentice-Hall 1939 Fed. Tax Serv. 14.56.

9. The only income reduction in the joint return comes from allowing one spouse to reduce his net gains by the net losses of the other. Since the aggregate income is treated as that of an individual for surtax purposes, the convenience of filing one return for both would otherwise be more than offset in the higher income brackets by the additional surtax rate imposed. 53 Staт. 5 (1939), 26 U. S. C. A. \$12 (1940). 
however, in the many situations under the statute where a decluction is dependent upon the "taxpayer's" income, because limited to his gains from a certain source, or to a percentage of his income or to a maximum total for each "taxpayer." The confusion which faces the tax lawyer who attempts to forecast the treatment of such deductions is indicated by a comparison of two circuit court opinions, Pierce v. Commissioner ${ }^{10}$ and Janncy v. Commissioner, 11 the latter now pending before the Supreme Court. ${ }^{12}$

Upon their facts the cases are indistinguishable; each concerned the deductibility of one spouse's stock transactions losses from the other's gains from the same source. Joint returns were made in each case under identical sections of different statutes, ${ }^{13}$ interpreted by identical regulations which provided that "all deductions to which either is entitled shall be taken from such aggregate income." 14 Both involved an interpretation of similar sections limiting loss deductions from stock transactions to a maximum of the "gains from such sales or exchanges." 15 The Commissioner determined that the limitation was to be computed without regard to the gains and losses of the other spouse. ${ }^{16}$ The Pierce decision upheld the Commissioner's contention, but in the Janney case the husband was permitted to deduct his losses from his wife's gains.

The conflict in the decisions is fundamental. They depend upon directly opposing views of the underlying theory of joint returns. ${ }^{17}$ In interpreting the capital loss provision involved in the Janney case, the Supreme Court will therefore settle the basic question of whether husband and wife in filing a joint return are two taxpayers or a single taxable unit. ${ }^{18}$ Adoption of

10. 100 F. (2d) 397 (C. C. A. 2d, 1938), (1939) 27 Geo. L. J. 1145; followed in Nelson v. Comm'r, 104 F. (2d) 521 (C. C. A. 4th, 1939); Sweet v. Comm'r, 102 F. (2d) 103 (C. C. A. 1st, 1939), cert. denied, 307 U. S. 627 (1939).

11. 108 F. (2d) 564 (C. C. A. 3d, 1939), (1940) 53 Hanv. L. Rev. 681.

12. Certiorari was granted by the Supreme Court on April 29, 1940. \& U. S. L. WEEK 726 (U. S. 1940).

13. Revenue Act of 1932, §51(b) (2); Revenue Act of 1934, $\$ 51$ (b) (2).

14. (1932) U. S. Treas. Reg. 77, Art. 381; (1934) U. S. Treas. Reg. 86, Art. 51-1. (Italics supplied).

15. Revenue Act of 1932, $\$ 23(\mathrm{r})$; Revenue Act of $1934, \S 117$ (d).

16. After the Pierce decision the Commissioner's views were put into United States Treasury Regulation 86, Art. 117-5: "In the application of $\$ 117$ a husband and wife, regardless of whether a joint return or separate returns are made, are considered to bc separate taxpayers." This provision has been repeated in substance in all Regulations since 1934.

17. Compare ". . . when they file a joint return ... . each is treated as a separate individual who can carry deductions into the joint return only in his or her own right," [Pierce v. Comm'r, 100 F. (2d) 397,398 (C. C. A. 2d, 1938)] with ". . . in arriving at joint net income both gross income and deductions of the spouses must be aggregated and treated as the income and deductions of a single taxpayer." [Janney v. Comm'r, 108 F. (2d) 564,566 (C. C. A. 3d, 1939)].

18. It has been suggested that the speculation factor may be used as a basis for distinguishing the stock transaction cases from those involving other limited deductions, thus 
either view will dictate the interpretation of many separate provisions of the revenue law.

One distinct factual variation is provided by the limited deduction for charitable contributions, illustrated by a case recently decided by the Second Circuit Court of Appeals. ${ }^{19}$ Section 23(o) of the Revenue Act of 1934 permitted a deduction for charitable gifts of an amount up to "15 per centum of the taxpayer's net income." The Regulations provided that the " 15 per cent limitation on the deduction for contributions or gifts is based on the separate net income . . . of the spouse making the contributions or gifts." 20 The petitioners' aggregate net income was $\$ \$ 3,682.99,21$ of which $\$ 12.10$ was traceable to the wife. She had made charitable contributions of $\$ 1,477$ (well within 15 per cent of their joint income). The Board of Tax Appeals allowed a deduction of only $\$ 1.81 .2$ Affirming without opinion, on the authority of the Pierce case, the circuit court decided that the deduction was properly limited to 15 per cent of the wife's income, rejecting the taxpayer's theory that it should be based on the spouse's combined income. An identical choice of underlying theory must be made in the Janncy case.

The clearest circuit court statement of the doctrine that a husband and wife who file a joint return remain separate taxpayers is found in the cases concerning the privilege of carrying over an unallowed capital loss for purposes of deduction the following year. ${ }^{23}$ On the analogy of affiliated corporations under a consolidated return,, 9 in which he filed a separate return have been disallowed as deductions from

considerably restricting the implications of the fortheoming Jamsy decision. (19:10) 53 HARV. L. REV. 681, 682.

Yet the only ground indicated by Congress for limiting the deductibility of securities losses in the 1932 Act contained no hint of restricting husband-wife pooling; it was solely that of "preventing such losses from wiping out ordinary income." It was stipulated that "security gains should not be taxed until they actually exceed security losses." Se:. REP. No. 655, 72d Cong., 1st Sess. (1932), 1939-1 Cusc. BulL 496, 503. Moreover, the cases indicate that a decision of the limited deductions problem involved in the carital loss situation will be a strong precedent for the other situations hercafter considered in the text. See Pierce v. Comm'r, 100 F. (2d) 397, 398 (C. C. A. 2d, 1938). It thus appears that the treatment of husband and wife in the capital gains situation deponds upon nothing peculiar in that limitation but upon the interpretation to be given to the broad joint returns section ( $\$ 51 \mathrm{~b})$.

19. Taft v. Comm'r, No. 234, Oct. Term (C. C. A. 2d, 1940).

20. U. S. Treas. Reg. \$6, Art. 23(0)-1.

21. The case involves petitioners' income for both 1934 and 1935. For simplicity of illustration, only the 1934 figures are here used.

22. Henry W. Taft, 40 B. T. A. No. 42 (1939).

23. "Although the petitioners filed a joint return in 1930, each of them remained a separate and distinct taxpayer." Van Vleck v. Comm'r, 80 F. (2d) 217,213 (C. C. A. 2d, 1935), cert. denied, 298 U. S. 656 (1936).

24. Compare Woolford Realty Co. v. Rose, 286 U. S. 319 (1932) and Kaiwili Sugar Co., Ltd., 21 B. T. A. 997 (1930), with Samuel G. Adams, 19 B. T. A. 781 (1930) and William H. Shelmerdine, 24 B. T. A. 833 (1931). 
the gains of his wife in a joint return for the following year. ${ }^{25}$ Wagering losses constitute another analogous item limited as to deductibility by the source of the income from which they may be subtracted. ${ }^{20}$ The analogy of such losses to capital losses has been made stronger by the Revenue Act of 1938 which, returning to the 1932 treatment of capital gains and losses, ${ }^{27}$ segregates short term losses from ordinary income because of their speculative nature.

Analysis of other factual possibilities reveals that acceptance of the single taxpaying unit theory will not result in revenue loss in every joint return situation to which it is applied. To take a factual variation under the capital loss deduction: Section 117-d of the Revenue Act of 1936 permits a deduction of $\$ 2000$ of capital loss from ordinary income; the rest may be deducted only from capital gains. Thus, if each spouse had a substantial income, no capital gains and large capital losses, each would take the $\$ 2000$ deduction under the separate taxpayer theory of the Pierce case. Under the single taxable entity theory, however, the $\$ 2000$ would be taken only once. That reventies would be increased in certain situations by a reversal of the Picrce decision is further illustrated by applying the charitable contributions deduction to another set of facts. Suppose that on a joint return the husband has a $\$ 50,000$ net income, including no capital gains or losses and exclusive of a deduction for charitable contributions. His wife has a $\$ 10,000$ net, long term capital loss. The husband has made contributions to charity totaling $\$ 8,000$. If in their joint return they were treated as separate taxpayers, the deduction of " 15 per centum of the taxpayers net income" 28 would be taken before aggregating their incomes. ${ }^{20}$ The husband's charitable deduction would be $\$ 7500(15 \%$ of $\$ 50,000)$ and the taxable aggregate income would be $\$ 40,500$. Under the Janney theory, however, the "taxpayer" would be the husband-wife unit. The wife's $\$ 2000$ capital loss would be deducted before reckoning that unit's net income. As a result only $\$ 7,200$ (15\% of $\$ 48,000$ ) could be deducted, leaving a joint taxable income of $\$ 40,800$.

In considering the credits granted for income from government bonds and for "earned income," the theory behind the joint return again becomes important. Regulations exempt from surtaxes the "interest on an aggregate of not exceeding $\$ 5,000$ principal amount of these obligations." 30 If, following the Janney decision, both incomes and deductions be treated as those of one taxpayer, only a single $\$ 5000$ deduction would be allowed. But if, as the Pierce case held, "on the joint return each [spouse] is treated as a

25. Van Vleck v. Comm'r, 80 F. (2d) 217 (C. C. A. 2d, 1935), cert. denicd, 298 U. S. 656 (1936).

26. 53 Stat. 13 (1939), 26 U. S. C. A. $\$ 23(h)$ (1940).

27. H. R. Rep. No. 1860, 75th Cong., 3d Sess. (1938), 1939-1 Curr. Burz. 733; Compare Revenue ACt of 1932, §23(r) (1) with Revenue ACT of 1938, §117(d) (2).

28. 53 Stat. 14 (1939), 26 U. S. C. A. §23(o) (1940).

29. See U. S. Treas. Reg. 101, Art. 23(o)-1.

30. U. S. Treas. Reg. 101, Art. 22(b) (4) -4. 
separate individual who can carry deductions into the joint return . . . in his or her own right" it would follow that each spouse could exempt the income from the first $\$ 5000$ worth of government bonds which he held. The Treasury Department has allowed such an interpretation. ${ }^{31}$ Similarly, Treasury Rulings allow each individual to deduct an earned income credit from his earned net income although husband and wife have filed a joint return. ${ }^{32}$

It is in the light, then, of its effect upon the many analogous deductions for which it will be the sole authoritative precedent that the anticipated Supreme Court decision must be evaluated. Arguments are available to both parties that Congress has sanctioned a particular regulation by reenactment of the section it interprets. ${ }^{33}$ The statutory provision which prohibits the taxpayer from deducting losses that result from sales "directly or indirectly" to his family offers a possible argument in favor of the single entity theory. ${ }^{3-2}$ But this provision applies to taxpayers under either joint or separate returns. Moreover, the statute, like the case authority it overturned, ${ }^{35}$ rules merely upon the effect to be given to intra-family transactions at a time when the parties are distinct taxpayers. ${ }^{36}$ It carries no implication as to the unity or separateness of the husband and wife when they are computing "aggregate income" under a joint return. Indeed, the revision was directed at closing an avenue of tax evasion which, because of their economic solidarity and the

31. I. T. 2855, XIV-1 Cuar. Burn. 72 (1935).

32. 53 Stat. 17 (1939); 26 U. S. C. A. \$25(2) (1940); I. T. 2875, XIV-1 Cu2s. BULL. 81 (1935).

33. The Commissioner urges that U. S. Treas. Reg. 86, Art. 117-5 has tsen given approval by the reenactment of a provision limiting the deduction of expital losses in the Revenue Acts of 1936 and 1938. The taxpayer urges on the other hand that, until the Pierce decision, the regulations interpreting $\$ 51(\mathrm{~b})$ favored cross deductions, as eridenced by the Commissioner's letter cited supra note 4; and that, after the Picrec interpretation was put into the Regulations, Art. $117-5, \$ 51$ (b) was amended after only one reenactment to make the spouses jointly and severally liable for the tax levied upon their joint return. Janney v. Comm'r, 108 F. (2d) 564, 567 (C. C. A. 3d, 1939). As to the weakness of arguments based upon the sanctioning of regulations by reenactment of the statute, see F. W. Woolworth Co. v. United States, 91 F. (2d) 973, 976 (C. C. A. 2d, 1937); cf. Hartley, Ex'r v. Comm'r, 295 U. S. 216, 220 (1935). Paul, Use and Abusse of Tax Regulations in Statutory Construction (1940) 49 YALE L. J. 660.

34. 53 Stat. 16 (1939), 26 U. S. C. A. \$24(b) (1) (1940).

35. Commissioner v. Thomas, 84 F. (2d) 562 (C. C. A. 5th, 1936); Commissioner v. Hale, 67 F. (2d) 561 (C. C. A. 1st, 1933); Joseph E. Uihlein, 30 B. T. A. 399 (1934). Husband and wife were formerly treated as individuals for purposes of $\$ 118$, the "wash" sale provision. Frank B. Gummey, 26 B. T. A. 894 (1932). Whether these cases have been similarly overturned by $\$ 24(\mathrm{~b})(1)$, as involving sales "indireetly" to the taxpayer's family, remains uncertain.

36. The term "loss" has been loosely applied to what was strictly a "bad debt" under $\$ 214$ (a) (7) of the Revenue Act of 1918. See Frank B. Gummey, 26 B.T.A. 894, 896 (1932). However, $\$ 24$ (b) (1) should not affect the allowance of "bad debt" sustained by a husband in a transaction with his wife. Elizabeth N. C. Hetherington, 20 B.T.A. 805 (1930) ; William M. Fleitmann, Jr., et al., Ex'rs, 22 B.T.A. 1291 (1931). 
difficulty of disproving "bed chamber" arrangements, had been open to families under either form of return. ${ }^{37} \mathrm{~A}$ more persuasive statutory argument for the combined unit treatment is the provision making the husband and wife who file a joint return jointly and severally liable for the tax assessed.88 The reason given for that legislation, however, was administrative expediency. ${ }^{39}$ In other procedural and administrative details, even where a joint return has been filed, the concept of individuality has been preserved. ${ }^{40}$ It thus appears that either disposition of the Janney case could find doctrinal justification.

Inasmuch as the decision of the Janney case will involve no constitutional question, but merely one of restricting a privilege important only to spouses in the higher surtax brackets, the best evaluation of results is in terms of revenue rather than doctrine. To the extent that an acceptance of the indi,viduality theory by the Supreme Court will actually prevent the deduction of one spouse's capital losses from the capital gains of the other on joint returns for past years still to be litigated, reversal of the Janncy decision seems the better result. The revenue yield of such capital loss restrictions would outweigh the loss of revenue that would result from applying this theory throughout the statute. To sanction the unit theory of the Janney case would merely increase the deduction privileges of an already privileged class, ${ }^{41}$ thereby shifting the tax burden upon other taxpayers by a general increase in tax rates or by alterations in the tax statute. A further disadvantage would be the inevitable costs of litigation following every such statutory change.

Even if the individuality theory be adopted by the Supreme Court, however, the Janney case may have little effect on revenue yield so far as its

37. H. R. REP. No. 704, 73d Cong., 2d Sess. (1934), 1939-1 Cun. BurL. 554, 571; 78 CoNG. Rec. 2662 (1934).

38. 52 Stat. 476 (1938), 26 U. S. C. A. § 51b (1940). Cf. Cole, Ex'r v. Comm'r, 81 F. (2d) 485 (C. C. A. 9th, 1935); Commissioner v. Rabenold, 4 Prentice-Hall 1940 Fed. Tax Serv. $\llbracket 62.359$ (C. C. A. 2d, 1940).

39. H. R. ReP. No. 1860, 75th Cong., 3d Sess. (1938), 1939-1 Cum. Bulu. 728, 749.

40. United States v. Hammerstein, 20 F. Supp. 744 (S. D. N. Y. 1937) (assessment against husband does not toll the statute of limitations on wife's liability for deficiency on joint return) ; Reynolds v. Glenn, 353-A C. C. H. 1935 Fed. Tax Serv. 19415 (W. D. Ky. 1935) (deficiency notice on joint return sent to husband is not notice to wife); Ethel Weisser, 32 B. T. A. 755 (1935) (wife separate person for purposes of appeal). But $c f$. Joseph Carroro, 29 B. T. A. 646 (1933) (both spouses liable for penalty for fraud of one on joint return); Frank A. Weinstein, 33 B. T. A. 105 (1935) (fraudulent return); O. D. 521, (1919-21) 2 CuM. Bull. 203 (1920) (extension of time to file joint return granted one spouse inures to both).

41. In addition to the joint return alternative, married persons receive additional personal exemptions. E.g., 53 Stat. 17 (1939), 26 U. S. C. A. $\$ 25(b)(1)$ (1940); Brushaber v. Union Pac. R. R., 240 U. S. 1 (1916) (constitutional). This favored treatment is based on a recognition of a difference in ability to pay. $H$. R. REp. No. 704, 73d Cong., 2d Sess. (1934), 1939-1 Cun. Bull. 554; cf. Garrecht, J. in Cole, Ex'r v. Comm'r, 
own fact situation (stock transactions) is concerned. Because of their separate identities in relations other than the joint return, the husband and wife may utilize the gift provisions of the current statute ${ }^{42}$ as a means of deducting the entire loss. By resort to these provisions, the spouses may avoid the section which allows short-term capital losses ${ }^{43}$ only to the extent of shortterm capital gains,44 and the Regulations which require that, regardless whether joint or separate returns are filed, capital losses be computed without regard to the other spouse's capital gains and losses. ${ }^{45}$ Assume, for example, that $T$ has capital assets held for less than 18 months, now worth $\$ 20,000$ more than he paid for them. His wife has short term assets which have declined in market value by $\$ 20,000$. If $T$ gives his wife his appreciated assets, she takes his basis as her own. ${ }^{40} T$, in making the gift, must of course meet the requirements of a bona fide donation: a true intention to give $;^{47}$ acceptance by the donee $;^{48}$ transfer of title; and complete relinquishment of control. ${ }^{49}$ But if these criteria are satisfied, the motives for the gift are immaterial ${ }^{50}$ and the gain on a subsequent sale by his wife may be properly set off against her losses, ${ }^{51}$ provided, of course, that the sale has not been previously entered into by $T$. A gift of her depreciated assets to $T$ would not be similarly effective, however, as Section $113(a)(2)$ sets as the donee's basis for determining loss either the donor's basis or the fair market value, whichever is lower. ${ }^{52}$

The fuller possibilities of avoiding the capital gains tax, which are implicit in the theoretical individuality of husband and wife under the tax statutes, become apparent in a further example. Assume that $T$ has long term capital

81 F. (2d) 485,487 (C. C. A. 9th, 1935). Paul and Havens, supra note 5 at 256, n. 72, point out that "equality before the law is not necessarily identity of treatment."

42. 53 Stat. 10 (1939), 26 U. S. C. A. $\$ 22$ (b) (3) (1940); 53 Sтлт. 40 (1939), 26 U. S. C. A. $\$ 113(a)(2)(1940)$. Of course a gift tax must be paid. 53 STAт. 144 (1939), 26 U. S. C. A. $\$ 1000(1940)$.

43. 53 Stat. 51 (1939), 26 U. S. C. A. $\$ 117$ (a) (5) (1940). Short term copital losses are defined as "loss from the sale or exchange of a capital asset held for not more than 18 months."

44. 53 Stat. 52 (1939), 26 U. S. C. A. $\$ 117$ (d) (1940).

45. U. S. Treas. Reg. 101, Art. 117-5(a).

45. 53 Stat. 40 (1939) 26 U. S. C. $\$ 113$ (a) (2) (1940).

47. "The intent of the donor of a gift, merely as a matter of his mental history is almost always irrelevant." L. Hand, J. in Richardson v. Smith, 102 F. (2d) 697, 699 (C. C. A. 2d, 1939). But his subsequent actions may determine his intent. T. C. Jaclison, 32 B. T. A. 470 (1935).

4S. Acceptance may be presumed. M. J. Hiatt, 22 B. T. A. 1245 (1931).

49. D. B. Malernee, 31 B. T. A. 662 (1934).

50. A donor's belief, though well founded, that he may later prevail over donce is not alone enough to invalidate a gift. Richardson v. Smith, 102 F. (2d) 697 (C. C. A. 2d, 1939) ; D. B. Malernee, 31 B. T. A. 662 (1934).

51. Bardach v. Comm'r, 90 F. (2d) 323 (C. C. A. 6th, 1937); and cases cited in notes 47-49 supra.

52. 53 StAT. 40 (1939). 26 U. S. C. A. $\$ 113(a)(2)$ (1940). 
assets now appreciated by $\$ 20,000$. He has a large additional taxable income. His wife has short term assets which have depreciated by $\$ 20,000$, but no short term capital gains. If $T$ transfers his assets to his wife by gift, she must add her holding period to that of $T^{53}$ The gains, when realized by her, would remain long term gains from which her short term losses would not be deductible. ${ }^{54}$ Nor would purchase at market value entitle the spouses to the deduction, for $T$ would thereby realize a long term capital gain. ${ }^{65}$ If, however, $T$ sells to his wife at his cost basis, he would not realize a gain from the transaction. ${ }^{56}$ Moreover, it is probable that his wife's basis for determining gain would be her own purchase price, and that for her computations the assets would have been transformed into short term assets dating from the purchase. This probability results from the acquiescence of the Treasury to the case of Reginald Fincke. ${ }^{57}$ There the taxpayer paid a gift tax on the difference between the market value of shares sold to his family and their purchase price, but credited himself with no capital gain. The Board of Tax Appeals upheld his position, concluding that he realized no profit from the transaction. Following the decision, the Treasury revoked a former office ruling which would have taxed as capital gain to $T$ the profit from the number of shares that the purchase price would have equalled at the then market value. ${ }^{58}$ The revocation also upset the former criterion for establishing the donee-vendee's basis after such a transaction, a formula which in the Fincke situation would have given the vendees as a basis the market value as to those shares represented in market value by the purchase price, and a gift, or donor's basis, as to the remaining shares. The Board's opinion noted with approval that the donees-vendees on their own returns used the "price paid" as the basis for reckoning their own capital gain. ${ }^{50}$ Whether the Board will similarly interpret the transaction in determining the date from which the holding period shall run has not been decided. The Fincke case indicates, however, that it will also be deemed a purchase for this purpose.

That some such rearrangement of assets between the spouses could prevent any substantial revenue increases that might otherwise result from a decision in favor of the Commissioner in the Janney case illustrates the ineffectiveness of patching an inadequate statute with isolated decisions. The revenue weakness inherent in the statute's attitude toward the marital relationship suggests a more complete remedy: discard the legalistic theory of separate identities and compute the spouses' tax on their joint income.

53. 53 StAT. 52 (1939), 26 U. S. C. A. $\$ 117$ (h) (2) (1940).

54. 53 Stat. 52 (1939), 26 U. S. C. A. $\$ 117$ (d) (1940).

55. Such a gain would be taxed to the husband although he could not deduct any loss realized in a sale to his wife. See note 33 supra.

56. 53 Stat. 37, 40 (1939), 26 U. S. C. A. \$§ 111, 113 (1940).

57. 39 B. T. A. 510 (1939).

58. I. T. $3335,1939-2$ Cum. Bull. No. 47 (Nov. 20, 1939) revoking I. T. 2681, XII-1 Cum. Bull. 93 (1933).

59. Reginald Fincke, 39 B. T. A. 510, 513 (1939). 
But such an answer faces constitutional objections. The leading decision discouraging such a statutory change is Hocper v. Ta.e Commission. ${ }^{\text {co }}$ In that case, Wisconsin attempted to tax a husband on the combined total of his own and his wife's income. The statute was held invalid on the ground that ". . . any attempt to measure the tax on one person's property or income by reference to the property or income of another is contrary to due process of law ..." 01 This statement, by itself, would seem to be a serious barrier to any proposal that computations be made upon the joint incomes of husband and wife; but it must be considered in its context. The tax statute there involved did not apportion the tax between the spouses. The state levying the tax had expressly made a wife's income her separate property. Moreover, three Justices dissented, reasoning that "taxation may consider not only command but actual enjoyment of the property taxed," and pointing to the ". . . community when two spouses live together and when usually each would get the benefit of the income of each without inquiry into the source." 62

This flow of benefit from family solidarity has steadily grown in importance as a factor in which the Court can find substantial taxable ownership in the head of a family. ${ }^{63}$ It has been enunciated most fully in the trust cases. In Burnet v. Wells the Supreme Court upheld as constitutional a tax upon the settlor of an irrevocable trust to pay premiums upon his life insurance policy. ${ }^{\text {os }}$ There was at least one other factor to which the decision might in part be attributed: the settlor's continuing right against repudiation evidenced some personal interest in the policy. But that the real basis for the decision was the flow of benefit test contended for by MIr. Justice Holmes in the Hocper case is evident in the majority opinion ${ }^{05}$ and emphasized by the dissent. ${ }^{60}$ The result depended upon recognition of the facts that the settlor was receiving a taxable benefit from the trust income and that the income, in providing for the security of the settlor's family, was performing his social obligation. This test of taxable ownership has been raised to new importance by the present Court's interpretation of the Revenue Act, which has shaped formerly innocuous sections into active revenue weapons. ${ }^{67}$ Since it is but a small step from the Wells opinion to a holding that a statute which enunciates the economic unity of the spouses for all tax purposes is constitutional, such a result would seem to be well within the stride of the Court. A forecast of

60. 284 U. S. 206 (1931).

61. Id. at 215 .

62. Id. at 219. Mr. Justice Holmes wrote the dissenting opinion.

63. See Helvering v. Clifford, 60 Sup. Ct. 554 (U. S. 1940), (1940) 49 YALE L. J. 1305.

64. 289 U. S. 670 (1933).

65. "The solidarity of the family is to make it possible for the taxpayer to surrender title to another and to keep dominion for himself, or if not teclunieal dominion, at least the substance of enjoyment." Id. at 677 .

66. Id. at 683 .

67. Helvering v. Clifford, 60 Sup. Ct. 554 (U. S. 1940), (1940) 49 YAIE L. J. 1305. 
constitutionality seems even more reasonable in the light of such considerations as protecting the revenue, preventing tax evasion, and removing the inequalities between married and single taxpayers ${ }^{68}$ and between married taxpayers in community property states and other states. ${ }^{00}$

The form the statute should take is debatable. Two possibilities are suggested by the limitations in the factual situation of the Hoeper case. That case involved a state tax and a state determination of status. Although Congress has accepted the status of married persons as fixed by the states, ${ }^{70}$ principles analogous to those justifying the taxation of common law trusts and associations might give Congress wider latitude to disregard such state determinations. ${ }^{71}$ Indeed, since the Constitution does not define "income" or "taxpayer," it has been urged ${ }^{72}$ that those terms should be given their common law meaning, ${ }^{73}$ thereby enabling Congress to tax the entire combined income to the husband, who at common law was entitled to possession. ${ }^{74}$

A less ingenious but more plausible suggestion is that in computing the taxes payable by husband and wife living together, the levy should be based upon their combined income and should be borne by each spouse in the proportion which his or her income bears to the whole. ${ }^{75}$ England so taxes the spouses' income. ${ }^{76}$ Such a statute would be outside the prohibitions of the Hoeper case, since Wisconsin in that case attempted to impose upon the husband the whole tax for the combined income. Another solution might be adoption of a prototype of the Canadian statute, ${ }^{77}$ which ignores transfers of property from one spouse to another and taxes income from such property to the one who first acquired it. ${ }^{78}$ The possibility of refusing deductions a matter of legislative grace - to spouses who do not file a joint return has been suggested by one authority. ${ }^{79}$

68. See supra note 41 .

69. Bruton, supra note 5 , at 1172 .

70. Poe v. Seaborn, 282. U. S. 101 (1930); cf. United States v. Robbins, 269 U. S. 315 (1926), resulting in Cal. Civ. Code (Deering 1937) \$161a. Bruton, supra note 5, at 1172 .

71. Burk-Waggoner Oil Ass'n v. Hopkins, 269 U. S. 110 (1925). But cf. Paul \& Havens, supra note 5 , at 270 .

72. Reiling, Taxing the Income of the Husband and Wife (1935) 13 TAx MaG. 198, 201.

73. This is an accepted rule of construction. United States v. Wong Kim Ark, 169 U. S. 649 (1897); see Standard Oil Co. v. United States, 221 U. S. 1, 59 (1910).

74. See Mr. Justice Holmes, dissenting in Hoeper v. Tax Comm., 284 U. S. 206, 218 (1931). But $c f$. Poe v. Seaborn, 282 U. S. 101 (1930) (Commissioner's attempts to tax husband upon entire community income under the current statute unsuccessful).

75. Bruton, supra note 5, at 1193.

76. Finance Act, $1927,17 \& 18$ Geo. V, c. $10, \S 42(9)$.

77. Canadian Income Tax Act, 1926, 16 \& 17 Geo. V, c. $10, \S 7$.

78. A possible precedent for such a statute is Reinecke v. Smith, 289 U. S. 172 (1933).

79. Paul and Havens, supra note 5 , at 270 . 
Despite the doubts which may be raised as to the validity of any of the forms of revision suggested, the present situation in regard to the tarition of husband and wife makes such an experiment desirable. Single decisions too often merely put a premium upon the ingenuity of tax lawyers. If the revenue loss which now arises from financial arrangements made between spouses solely for purposes of tax avoidance is to be averted, legislative recognition of the economic unity of the family seems necessary. 